\title{
Distracted pedestrian sustains orbital fracture while on cell phone
}

This article was published in the following Dove Press journal:

Clinical Ophthalmology

2 April 2013

Number of times this article has been viewed

\author{
Aimée R Edell \\ Jesse J Jung \\ Joel M Solomon \\ Richard N Palu \\ Department of Ophthalmology, \\ New York University School \\ of Medicine, New York, NY, USA
}

Correspondence: Aimée Edell

31723 Ist Street, Apartment 3H, Astoria,

New York, NY I I 106, USA

Tel +l 6463824845

Fax + I 2122638749

Email aimeeedell@gmail.com

\begin{abstract}
Use of cell phones in the general population has become increasingly commonplace. The distracting effects of cell phones among automobile drivers are well established, and legislation prohibits the use of handheld cell phones while driving in several states. Recent research has focused on the similar distracting effects of cell phones in the pedestrian population. In this report, an older gentleman suffered extensive facial trauma requiring surgery as a direct effect of cell phone use at the time the trauma occurred. This case highlights the role that portable electronic devices can play as a cause of ocular trauma.
\end{abstract}

Keywords: orbital fracture, ocular trauma, orbital floor fracture, cell phone distraction, pedestrian safety

\section{Case report}

A 72 year old man presented with new-onset pain with eye movement and diplopia. One day prior to presentation, he had accidentally struck his face on a metal fence while walking on a city street at night. He reported using a handheld cell phone device when the incident occurred. While actively engaged in conversation, he had walked into the corner pole of a metal fence and struck his left eye area. He was wearing spectacles at the time, which were scratched, but not shattered. He reported that he was not intoxicated and did not notice the object until after the trauma. He reported double vision on upgaze and pain in the left eye in all fields of gaze. Visual acuity was 20/20 OD and 20/20 OS. There was no relative afferent pupillary defect. Ocular range of motion was restricted in the left eye on upgaze with diplopia. No oculocardiac reflex or facial hypesthesia was apparent. There was minimal cutaneous ecchymosis and periorbital edema. Noncontrast computed tomography of the head and orbits revealed a depressed fracture of the left orbital floor with entrapment of the inferior rectus muscle (Figure 1). He was evaluated by an oculoplastic specialist for clinically significant left orbital floor fracture and advised to undergo exploration and repair of the fracture. The patient underwent transconjunctival exploration of the left orbital floor. Intraoperatively, a depressed defect in the orbital floor was noted, with herniation of the inferior rectus muscle into the maxillary sinus. The entrapped muscle and surrounding orbital fat were released from the fracture and forced ductions revealed satisfactory delivery of the tissue. Postoperatively, the patient regained full ocular range of motion without residual diplopia. He was returned to the care of his general ophthalmologist for further management. 


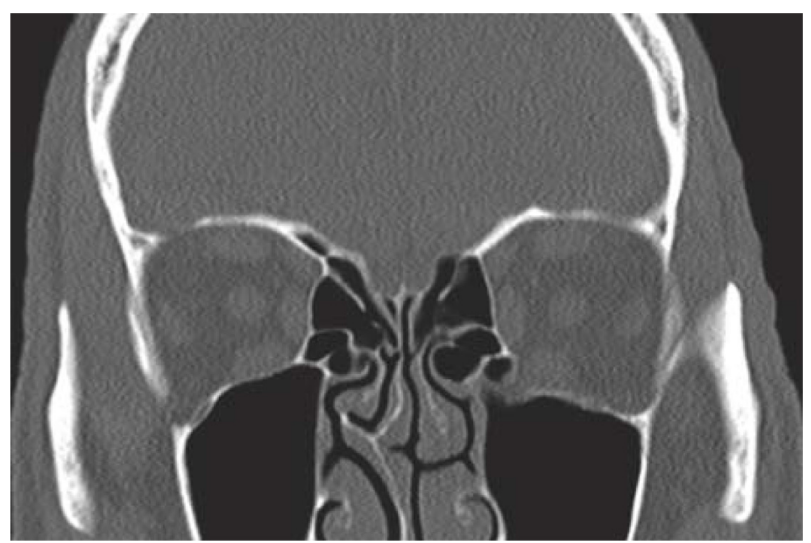

Figure I Preoperative coronal computerized tomography scan demonstrating a left inferior floor fracture with herniation of the inferior rectus and orbital fat contents inferiorly.

\section{Discussion}

Cell phone use has become ubiquitous worldwide over the past decade. In the United States, an estimated $80 \%$ of the population owns a cell phone. ${ }^{1}$ Several studies have demonstrated an increase in accident rates among drivers distracted by handheld cell phones, and legislation now limits the use of handheld cell phones by drivers in several states, beginning with New York State in 2001. 2,3

Only more recently have the distracting effects of cell phones been examined in the pedestrian population. In a study of passers-by in a large urban university campus, pedestrians talking on cell phones were significantly less likely than pedestrians holding cell phones but not engaging in conversation to recall planted objects set along a predefined route. Pedestrians talking on cell phones also displayed unsafe roadcrossing behavior at cross-walks significantly more often than did pedestrians without cell phones or pedestrians listening to portable music players. ${ }^{4}$ These findings were confirmed in subsequent analyses of college-aged pedestrians using handheld devices. ${ }^{5,6}$ The distracting effect of cell phones seems to be amplified in older individuals. ${ }^{7}$

Discussion of cell phone-related pedestrian morbidity has made its way into the public arena as well. A recent article in a major urban newspaper highlighted the story of a woman who suffered minor injuries after walking into a parked truck while talking to a family member on her cell phone. ${ }^{8}$ Interest has not only been directed to talking on cell phones; "text-walking" is becoming a popular term for pedestrians, often not attentive to their surroundings, who text while on the go. ${ }^{9}$ It is now apparent that texting while walking affects not only gait velocity but lateral deviation as well, placing text-walkers at risk for encountering unintended obstacles resulting in injury..$^{10}$ In New York, former Senator Carl Kruger sponsored a bill that would make crossing a city cross-walk while using an electronic device punishable by a $\$ 100$ fine, citing an incident wherein a young man was crushed by a truck after he stepped into the street while distracted by loud music on his headphones. ${ }^{11} \mathrm{~A}$ similar bill proposed in Arkansas was later dropped by Senator Jimmy Jeffress after it failed to gain popularity with constituents.

The number of pedestrians using cell phones in public traffic areas may only be expected to rise as these increasingly versatile devices gain even wider popularity. Ocular trauma among pedestrians and other road users associated with the use of electronic devices represents an increasing mode of injury of which ophthalmologists should be aware.

\section{Acknowledgment}

The authors would like to acknowledge the support of the New York University Department of Ophthalmology.

\section{Disclosure}

The authors report no conflicts of interest in this work.

\section{References}

1. Wilson J, Kimball R. Our cell phone use, by the numbers. 2010. Available from: http://www.cnn.com/2010/TECH/mobile/10/19/mobile.lives. quantified/index.html\%23. Accessed December 20, 2012.

2. New York State Police. Routine use of cellular telephones while driving is prohibited in New York State, pursuant to Vehicle and Traffic Law Section 1225c. Available from: http://troopers.ny.gov/traffic_safety/ Cell_Phones/. Accessed February 5, 2012.

3. Strayer D, Drews F, Crouch D. A comparison of the cell phone driver and the drunk driver. Hum Factors. 2006;48:381-391.

4. Nasar J, Hecht P, Wener R. Mobile telephones, distracted attention, and pedestrian safety. Accident Analysis and Prevention. 2008;40: 69-75.

5. Stavrinos D, Byington K, Schwebel D. Distracted walking: cell phones increase injury risk for college pedestrians. J Safety Res. 2011;42:101-107.

6. Schwebel D, Stavrinos D, Byington K, et al. Distraction and pedestrian safety: how talking on the phone, texting, and listening to music impact crossing the street. Accident Analysis and Prevention. 2012;45:266-271.

7. Neider M, Gaspar J, McMarley J, et al. Walking and talking: dual-task effects onstreet crossing behavior in older adults. Psychol Aging. 2011;26:260-268.

8. Richtell M. Forget gum. Walking and using phone is risky. New York Times, Technology section. Published January 16, 2010.

9. Urban Dictionary. Definition of textwalking. Available from: http:// www.urbandictionary.com/define.php?term=textwalking. Accessed July 22, 2012.

10. Lamberg E, Muratori L. Cell phones change the way we walk. Gait Posture. 2012;35:688-690.

11. New York Senate Bill 1945. Available at: http://open.nysenate.gov/ legislation/bill/S1945-2011. Accessed February 5, 2012. 
Clinical Ophthalmology

\section{Publish your work in this journal}

Clinical Ophthalmology is an international, peer-reviewed journal covering all subspecialties within ophthalmology. Key topics include: Optometry; Visual science; Pharmacology and drug therapy in eye diseases; Basic Sciences; Primary and Secondary eye care; Patien Safety and Quality of Care Improvements. This journal is indexed on

PubMed Central and CAS, and is the official journal of The Society of Clinical Ophthalmology (SCO). The manuscript management system is completely online and includes a very quick and fair peer-review system, which is all easy to use. Visit http://www.dovepress.com/ testimonials.php to read real quotes from published authors. 